http://dx.doi.org/10.11646/phytotaxa.116.1.3

\title{
Knautia dinarica (Caprifoliaceae): taxonomy, typification and update of the Italian distribution
}

\author{
LORENZO PERUZZI ${ }^{1}$, FABRIZIO BARTOLUCCI ${ }^{2}$, GIOVANNI ASTUTI ${ }^{1}$, LILIANA BERNARDO ${ }^{3} \&$ \\ FABIO CONTI ${ }^{2}$ \\ ${ }^{1}$ Dipartimento di Biologia, Unità di Botanica, Università di Pisa, Via Luca Ghini 13, 56126, Pisa, Italy; \\ e-mail: lperuzzi@biologia.unipi.it \\ ${ }^{2}$ Scuola di Scienze Ambientali, Università di Camerino - Centro Ricerche Floristiche dell'Appennino (Parco Nazionale del Gran \\ Sasso-Laga), S. Colombo, 67021 Barisciano (L'Aquila), Italy \\ ${ }^{3}$ Orto Botanico, Università della Calabria, 87030 Arcavacata di Rende (Cosenza), Italy \\ * author for correspondence
}

\begin{abstract}
New Italian populations of Knautia dinarica, formerly known only for Sila (Calabria, Southern Italy), were discovered in Abruzzo (Central Italy) and Basilicata (Southern Italy). In order to correctly classify these populations, a taxonomic study was carried out, including morphological and karyological analyses and the typification of the names Knautia sylvatica var. dinarica and $K$. arvensis f. silana. We conclude that in Italy only $K$. dinarica subsp. silana occurs, to be considered as endemic to central-southern Apennines and vicariant of $K$. dinarica subsp. dinarica, occurring in the Balkan peninsula. Both subspecies can be either diploid $(2 n=20)$ or tetraploid $(2 n=40)$, and are distinguished by the different mean shape of the basal leaves (the ratio length/width is higher in Italian plants).
\end{abstract}

Key words: Dipsacaceae, Dipsacales, karyology, Knautia, taxonomy, typification

\section{Introduction}

The dipsacaceous clade within Caprifoliaceae (Dipsacales) contains ca. 300 herbaceous species, mostly distributed in the Mediterranean area, Knautia Linnaeus (1753: 101) representing a monophyletic genus with 40-60 species (Carlson et al. 2009). Knautia dinarica (Murbeck 1891: 111) Borbás (1894: 399) is currently known from Balkan Peninsula (in the former Jugoslavia, Albania, and Bulgaria countries) and Southern Italy (Calabria region) (Ehrendorfer 1976, Conti et al. 2005). Verlaque (1977) reported K. dinarica also from Greece, but this record was not confirmed in recent Checklists or Floras (Greuter et al. 1986, Strid \& Tan 1991). Knautia dinarica subsp. dinarica occurs in the Balkans (mostly on limestones), while in Italy (on siliceous substrates, see Sarfatti 1965, Brullo et al. 2007) only the narrow endemic K. dinarica subsp. silana (Grande 1913: 107) Ehrendorfer (1975: 40) is reported. On the basis of the literature data, the subsp. silana differs from the nominal one in hair-type and petiole length of basal leaves (Ehrendorfer 1975, 1976, 1982a). During field research in Central and Southern Italy, we found two populations of Knautia dinarica s.l. well outside the historical range and growing on calcareous substrate: the first one in Abruzzo region (Central Italy), the second one in Basilicata region (Southern Italy). In order to correctly classify these populations, we carried out a taxonomic study, including morphological and karyological analyses and the typification of the names involved. This work is also carried out within the initiative "Italian Loci Classici Census" (Domina et al. 2012), launched in 2010 under the auspices of the Italian Botanic Society (see for instance Di Pietro et al. 2012, Gallo et al. 2012, Iamonico \& Peruzzi 2012, Peruzzi \& Carta, 2013, Peruzzi et al. 2012, 2013, Iamonico 2013, Bartolucci \& Conti 2013, Bartolucci \& Peruzzi 2013). 


\section{Material and Methods}

This study is based on the analysis of relevant literature, field surveys and revision of herbarium specimens (including the original material for the names studied) kept in APP, BEOU, CLU, FI, LD, NAP, PI and WU (acronyms follow Thiers 2012).

Despite a casual variation of the characters usually used to distinguish the two taxa was evident since our first observations, we noted on the contrary some variation in basal leaves size among the studied plants. For this reason, we decided to measure the following three characters: basal leaves length $(\mathrm{cm})$, basal leaves width $(\mathrm{cm})$, ratio basal leaves length / basal leaves width $(\mathrm{L} / \mathrm{W})$. Quantitative morphological investigation is performed on a total of 61 herbarium specimens of $K$. dinarica: 26 from Calabria (Southern Italy, fully corresponding to $K$. dinarica subsp. silana), 11 from the Balkans (fully corresponding to $K$. dinarica subsp. dinarica), 11 from Basilicata (Southern Italy, coded as BAS) and 13 from Abruzzo (Central Italy, coded as ABR). While ABR and BAS occur in single populations, the measurements of subsp. dinarica and subsp. silana were taken from samples coming from several localities (cfr. Appendix 1). The variables were processed singularly by means of ANOVA (after check of Levene statistics) with Tukey HSD test for comparing the same variable among pairs of Operational Taxonomic Units (OTU), using SPSS® 20 for Windows (SPSS, Chicago, IL, USA).

As regards the chromosome analysis, squash preparations were made from root-tips of plants cultivated in the Botanic Garden of Floristic Research Center of the Apennine [Polledrara, Secine (Palena), 430312N, 4638996E (UTM-ED50), $1730 \mathrm{~m}, 20$ July 2006, F. Conti (acc. n. 236/06)], according to the following schedule: pretreatment in $0.4 \%$ colchicine solution for 4 hours; Carnoy fixing for 45 min; hydrolisis in $\mathrm{HCl}$ $1 \mathrm{~N}$ for 6 minutes at $60^{\circ} \mathrm{C}$; staining with leuco-basic fuchsin for 3 hours.

\section{Typification of the names}

Knautia dinarica (Murb.) Borbás (1894: 399)

Bas.:-Knautia sylvatica var. dinarica Murbeck (1891: 111). Type (lectotype, here designated):-BOSNIAHERZEGOVINA. In pratis alpinis Matorac montis Vranica planina, 1800-1900 m, 9 September 1889, Murbeck 1165781 (LD!; isolectotype WU! No. 0044885).

Knautia sylvatica var. dinarica was described from Bosnia-Herzegovina and Montenegro (Vranica and Bjelasnica Mountains) (Murbeck 1891). We traced eight herbarium sheets, kept in LD and WU, that were collected ante 1891 and match the protologue, so they can be considered as original material for the name. The best preserved and complete exsiccatum at LD is here selected as the lectotype. This specimen corresponds to the current concept of $K$. dinarica, but all the traced original material is showing only long hairs in the lower third of the individuals, in contrast with the description given by Ehrendorfer (1976), who refers to $K$. dinarica s.s. as a more or less pubescent plant showing also long hairs. According to the Art. 41.3 of the ICN (McNeill et al. 2012) the new combination Knautia dinarica (Murb.) Borbás was validly published (Borbás 1894), while the isonym proposed by Malý (1908: 233) has no nomenclatural status.

Knautia dinarica subsp. silana (Grande) Ehrendorfer (1975: 40)

Bas.:-Knautia arvensis f. silana Grande (1913: 107). Type (neotype, here designated):-ITALY. Calabria: Loc. Calabria, in ditione Longobucco, loco Fossiata dicto, in herbosis humidis, alt. $1300 \mathrm{~m}$, solo granitico, 7 August 1921, A. Fiori s.n. (FI! the specimen bearing also handwritings; isoneotypes in FI! and PI!).

Grande (1913: 107) refers to "Scabiosa arvensis B. foliis lanceolatis subintegerrimis" (Tenore 1831: 59) and to a number of localities with collections (e.g. syntypes) made by him together with F. Cavara ("Nelle pinete, nei prati o lungo i rivoli a Botte Donato, alla caserma della Fossiata") and together with G. Lopez ("ai Serriselli, al Pirillo, al Vallo d'Agnara, a Tacina"). We were not able to trace in NAP (neither in Tenore nor in 
Cavara-Grande collections) any of these specimens. Since no other original material were traced, we are forced to propose a neotype for this name. For this purpose, we selected a well representative, topotypical collection conserved in FI. According to the Art. 41.6 of the ICN (McNeill et al. 2012) the combination proposed by Ehrendorfer (1975) was validly published, despite the incorrect referring to basyonim's rank ("var.") and year of publication ("1911").

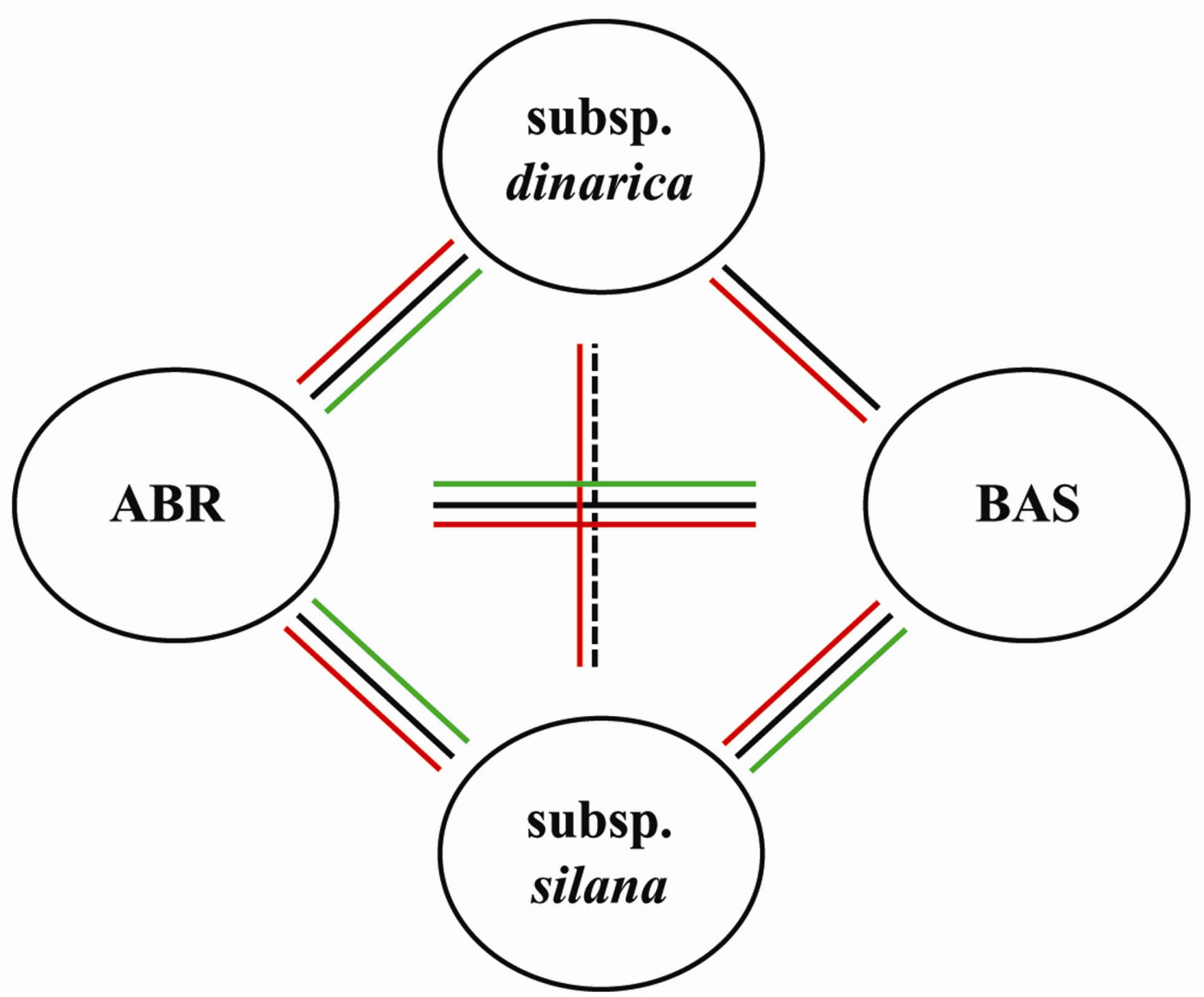

FIGURE 1. Graphic showing the morphological relationships (based on the basal leaf features) between Knautia dinarica subsp. dinarica $(\mathrm{N}=11), \mathrm{ABR}(\mathrm{N}=13)$, BAS $(\mathrm{N}=11)$ and $K$. dinarica subsp. silana $(\mathrm{N}=26)$. The presence of a continuous line between two OTUs evidences no statistically significant difference (Tukey HSD test); the presence of a discontinuous line between two OTUs evidences a difference significant at 0.05 level (Tukey HSD test); the absence of a line between two OTUs evidences a difference significant at 0.01 level (Tukey HSD test). Black lines = length; red lines = width; green lines = ratio L/W.

\section{Morphological and Karyological Results}

The relationships among the four considered OTUs are represented in Fig. 1 and Table 1. The width of basal leaves has not significance from the statistical point of view among the studied OTU (Tukey HSD test with $\mathrm{p}$ values ranging between 0.18 and 0.98). Concerning the length of basal leaves, there is no difference between subsp. silana / ABR / BAS and between subsp. dinarica / ABR / BAS (Tukey HSD test with p values ranging between 0.09 and 0.99), while moderately significant differences occur between subsp. dinarica / subsp. silana $(\mathrm{p}=0.05)$. By considering the covariance of these two morphological parameters (the ratio $\mathrm{L} / \mathrm{W}$ ), there is no significant difference between subsp. silana / ABR / BAS (Tukey HSD test with p values between 0.96 and 0.99) and between subsp. dinarica / ABR ( $\mathrm{p}=0.06)$, while subsp. silana and BAS differ significantly from subsp. dinarica $(\mathrm{p}=0.01)$.

The single studied population of $K$. dinarica from Abruzzo (ABR) turned out to be diploid with $2 n=20$ chromosomes. 
TABLE 1. Basal leaves morphological comparison in Knautia dinarica subsp. dinarica $(\mathrm{N}=11), \mathrm{ABR}(\mathrm{N}=13)$, BAS $(\mathrm{N}=11)$ and $K$. dinarica subsp. silana $(\mathrm{N}=26)$. Quantitative values are expressed as $10-90$ percentile intervals, with minimum and/or maximum in brackets.

\begin{tabular}{lcccc}
\hline & subsp. dinarica & ABR & BAS & subsp. silana \\
\hline basal leaves length $(\mathbf{c m})$ & $6-12.5(-17.1)$ & $(10-) 10.1-16.3(-20.5)$ & $(4-) 6.7-13.5(-17)$ & $(5-) 6.9-19.7(-28)$ \\
basal leaves width $(\mathbf{c m})$ & $(1.3-) 1.6-3.2(-3.8)$ & $(0.9-) 1.3-2.7(-2.9)$ & $(0.5-) 0.6-2.2(-3.7)$ & $(0.7-) 1-2.3(-3)$ \\
ratio L/W & $(3-) 3.3-7.0(-7.7)$ & $(4.7-) 4.8-10.5(-11.5)$ & $(4.6-) 4.7-11.8(-14)$ & $(4.5-) 4.9-9.6(-14)$ \\
\hline
\end{tabular}

\section{Discussion}

The traditional morphological features used to distinguish the two subspecies of Knautia dinarica (hair-type and petiole length in the basal leaves) are very inconstant, according to our own observations (data not shown) and in agreement with the study of the nomenclatural types. Our quantitative analysis of basal leaves dimensional features confirmed a substantial overlap in leaf length and width, among the two subspecies and the unassigned ABR and BAS OTUs. On the other hand, the ratio of these two morphological features (ratio $\mathrm{L} / \mathrm{W}$ ) revealed a statistically significant mean difference between subsp. dinarica and the most southern Italian populations, with ABR somehow linked to both subspecies. However, when performed between subsp. silana (circumscribed as including ABR and BAS) and subsp. dinarica, ANOVA evidences a difference in ratio $\mathrm{L} / \mathrm{R}(\mathrm{df}=2, \mathrm{~F}=12.338, \mathrm{p}=0.001)$. On the contrary, a narrower circumscription of subsp. silana (including only BAS) compared with a wider circumscription of the typical subspecies (including also ABR) showed only moderately significant differences $(\mathrm{df}=2, \mathrm{~F}=5.381, \mathrm{p}=0.02)$. Accordingly, and despite the weak and incomplete morphological differentiation, it seems actually opportune to keep the two subspecies distinct awaiting further morphological and molecular analyses: $K$. dinarica subsp. dinarica is confirmed as endemic to Balkans, $K$. dinarica subsp. silana, as here circumscribed, results endemic to central-southern Apennines, from Abruzzo to Calabria (irrespective of geological substrate, either calcareous or siliceous). The range of the latter subspecies is extended of about $350 \mathrm{~km}$ northwards (Fig. 2), and the plant could more common than expected in that area: for instance, a record of Knautia dinarica s.l. exists for a second locality in Basilicata, Mt. Volturino (Corbetta et al. 1986).

Previous chromosome counts have been reported for Knautia dinarica subsp. dinarica by Ehrendorfer (1962) from Bosnia $(2 n=20)$, Montenegro $(2 n=40)$, and Albania $(2 n=$ ca. 40$)$ and by Verlaque $(1977,1985)$ from Greece $(2 n=20)$. Ehrendorfer $(1975,1976,1982 b)$ reported also $2 n=40$ for $K$. dinarica subsp. silana from Sila (Calabria, S. Italy). By adding our count from Abruzzo into this framework, it can be concluded that both subspecies can be either diploid or tetraploid. A (recurrent) polyploidy is common in many groups of Knautia, including K. arvensis (Linnaeus 1753: 99) Coulter (1823: 29), which is phylogenetically closely related to $K$. dinarica (Carlson et al. 2009).

\section{Identification key for the Knautia dinarica subspecies}

With the aim to a correct identification, at least ten individuals per population are to be measured. We have verified that measurements taken on single individuals could lead to a wrong identification. For a general description of the species, refer to Ehrendorfer (1976).

1. Ratio basal leaves length / basal leaves width (3-)3.3-7(-7.7), endemic to Balkan peninsula.

K. dinarica subsp. dinarica

- Ratio basal leaves length / basal leaves width (4.5-)4.7-11.1(-14), endemic to Italian peninsula.

K. dinarica subsp. silana 


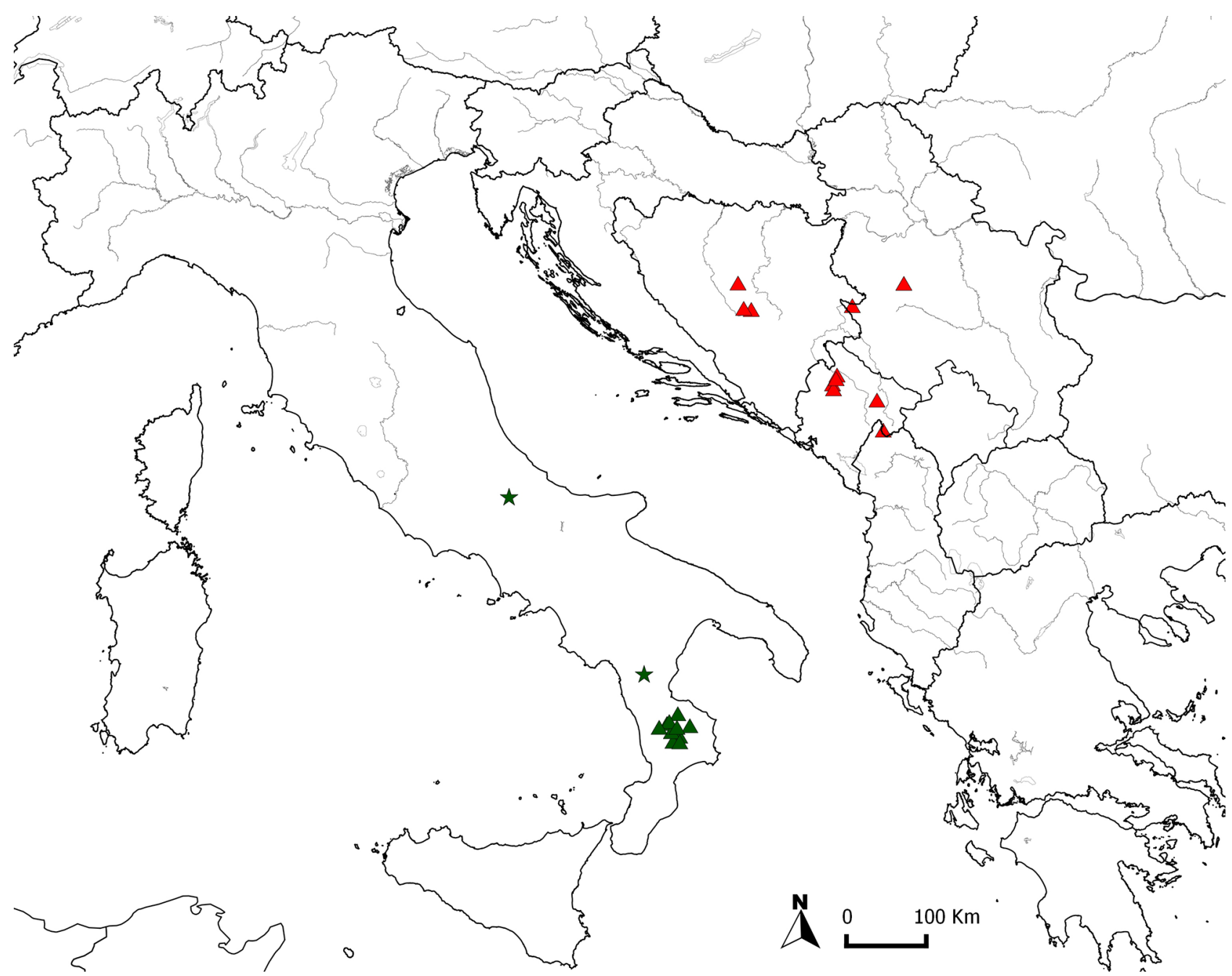

FIGURE 2. Distribution map of Knautia dinarica subsp. dinarica (red triangles) and $K$. dinarica subsp. silana (green triangles: historical populations; green stars: new populations) according to the studied material.

\section{Acknowledgements}

The authors are indebted with A. Thell (Herbarium LD), for sending the pictures of the Knautia sylvatica var. dinarica original material and for some observation at the stereomicroscope; with R. Vallariello (Università di Napoli "Federico II"), for information on Knautia specimens in Tenore and Cavara-Grande collections in NAP. The curators of FI and PI are also gratefully acknowledged for their kind help. Finally, many thanks are due to two anonymous reviewers who much improved an earlier version of the manuscript.

\section{References}

Bartolucci, F. \& Conti, F. (2013) Taxonomical notes on Geum micropetalum Gasp. ex Ten. and Geum heterocarpum Boiss. (Rosaceae) from Italy. Plant Biosystems 147: in press.

Bartolucci, F. \& Peruzzi, L. (2013) Thymus paronychioides (Lamiaceae), a neglected species from Sicily belonging to section Hypodromi. Folia Geobotanica 49. http://dx.doi.org/10.1007/s12224-013-9156-2.

Borbás, V. (1894) Flora von Oesterreich-Ungarn. Österreich Botanische Zeitschrift 44: 397-400.

Brullo, S., Gangale, C. \& Uzunov, D. (2007) Taxonomic remarks on the endemic flora of Sila mountain (S-Italy). Bocconea 21: 213-222. 
Carlson, S., Mayer, V. \& Donoghue, M.J. (2009) Phylogenetic relationships, taxonomy, and morphological evolution in Dipsacaceae (Dipsacales) inferred by DNA sequence data. Taxon 58: 1075-1091.

Conti, F., Abbate, G., Alessandrini, A. \& Blasi, C. (eds.) (2005) An Annotated Checklist of the Italian Vascular Flora. Palombi Editori, Roma, 420 pp.

Corbetta, F., Ubaldi, D., Puppi, G. (1986) Tipologia fitosociologica delle praterie altomontane del Monte Volturino e del Monte Madonna di Viggiano (Appennino Lucano). Biogeographia n.s. 10 (1984): 207-236.

Coulter, T. (1823) Mémorie sur les Dipsacées. Paschoud, Genève, 49 pp.

Di Pietro, R., Viscosi, V., Peruzzi, L. \& Fortini P. (2012) A review of the application of the name Quercus dalechampii. Taxon 61: 1311-1316.

Domina, G., Giusso Del Galdo, G., Gargano, D., Labra, M., Peccenini, S., Peruzzi, L. \& Raimondo, F.M. (2012) The Italian Loci Classici Census. Taxon 61: 1351-1353.

Ehrendorfer, F. (1962) Beiträge zur Phylogenie Der Gattung Knautia (Dipsacaceae), I. Cytologische Grundlagen und allgemeine Hinweise. Österreich Botanische Zeitschrift 109: 276-343.

Ehrendorfer, F. (1975) Taxonomic notes on Knautia L. In: Heywood, H.V. (ed.), Flora Europaea Notulae Systematicae ad Floram Europaeam spectantes 17. Botanical Journal of the Linnean Society 71: 39-41.

Ehrendorfer, F. (1976) Knautia. In: Tutin, T.G., Burges, N.A., Chater, A.O., Edmondson, J.R., Heywood, V.H., Moore, D.M., Valentine, D.H., Walters, S.M. \& Webb, D.A. (eds.) Flora Europaea 4. Cambridge University Press, Cambridge, pp. 60-67.

Ehrendorfer, F. (1982a) Knautia. In: Pignatti, S. (ed.), Flora d'Italia 2. Edagricole, Bologna, pp. 664-670.

Ehrendorfer, F. (1982b) Knautia. In: Moore, D.M. (ed.), Flora Europaea Check-list and Chromosome Index. Cambridge University Press, Cambridge, pp. 168-173, 221-222.

Gallo, L., Guglielmone, L. \& Nardi, E. (2012) Typification of Alyssum argenteum All. (Brassicaceae) and of Sedum alsinifolium All. (Crassulaceae), two Italian endemic taxa. Webbia 67: 183-188. http://dx.doi.org/10.1080/00837792.2012.10670918

Grande, L. (1913) Note di floristica Silana. Bollettino dell'Orto Botanico di Napoli 3: 93-110.

Greuter, W., Burdet, H.M. \& Long, G. (1986) Med-Checklist 3, Dicotyledones (Convolvulaceae-Labiatae). Conservatoire et Jardin botaniques, Ville de Genève, Genève, Berlin, 395 pp.

Iamonico, D. (2013) Taxonomic and chorological study on the central Mediterranean Basin endemic Arenaria bertolonii Fiori \& Paol. (Caryophyllaceae). Plant Biosystems. http://dx.doi.org/10.1080/11263504.2012.753956.

Iamonico, D. \& Peruzzi, L. (2012) Lectotypification of the Linnaean name Acanthus spinosus (Acanthaceae). Phytotaxa 62: 11-12.

Linnaeus, C. (1753) Species Plantarum 1. Laurentii Salvii, Stockholm, 560 pp.

Malý, K. (1908) Beitrage zur Kenntnis Der Illyrischen Flora. Magyar Botanikai Lapok 7: 203-240.

McNeill, J., Barrie, F.R., Buck, W.R., Demoulin, V., Greuter, W., Hawksworth, D.L., Herendeen, P.S., Knapp, S., Marhold, K., Prado, J., Prud'homme Van Reine, W.F., G. Smith, G.F., Wiersema, J.H. \& Turland, N.J. (eds.) (2012) International Code of Nomenclature for algae, fungi and plants (Melbourne Code): adopted by the Eighteenth International Botanical Congress Melbourne, Australia, July 2011. Regnum Vegetabile 154. Ruggell: Gantner, 232 pp.

Murbeck, S. (1891) Beitrage zur Kenntniss Der Flora von Sudbosnien und Der Hercegovina. Acta Universitatis Lundensis 27(5): 1-182.

Peruzzi, L., Adorni, M., Dura, T., Ghillani, L., Pasquali, G., Rignanese, L., Ronconi, D. \& Teruzzi, M. (2012) Allium cyrilli Ten. (Amaryllidaceae): typification, taxonomy and update of the Italian distribution. Phytotaxa 71: 53-58.

Peruzzi, L. \& Carta, A. (2013) A taxonomic revision of Silene nocturna species complex (Caryophyllaceae) in Italy. Phytotaxa 88: 38-48.

Peruzzi, L., Santangelo, A. \& Jarvis, C.E. (2013) Lectotypification of Linnaean names in the Italian endemic flora. Taxon 62: in press.

Sarfatti, G. (1965) Prodromo della flora della Sila (Calabria) parte II. Webbia 20: 355-425. http://dx.doi.org/10.1080/00837792.1965.10669820

Strid, A. \& Tan, K. (1991) Mountain flora of Greece 2. Edinburgh University Press, Edinburgh, 974 pp.

Tenore, M. (1831) Sylloge plantarum vascularium florae Neapolitanae. Fibreni, Napoli, 747 pp.

Thiers, B. (2012) Index Herbariorum: A global directory of public herbaria and associated 602 staff. Available at: http:/ /sweetgum.nybg.org/ih/ (accessed: 10 March 2013)

Verlaque, R. (1977) Reports. In: Löve, A. (ed.), IOPB chromosome number reports LVI. Taxon 26: $272-274$.

Verlaque, R. (1985) Étude biosystématique et phylogénétique des Dipsacaceae. III. Tribus des Knautieae et des Dipsaceae. Revue de Cytologie et Biologie Végétales - le Botaniste 8: 171-243. 
APPENDIX 1. Specimens of Knautia dinarica studied.

Knautia dinarica subsp. dinarica:-BOSNIA-HERZEGOVINA. Bosnia: in prat. alp. montis Vranica pl. (Matorac), 11 September 1889, S. Murbeck 1165481 (LD!); Bosnia: in pratis alpinis Matorac montis Vranica planina, 1800-1900 m, 9 September 1889, Murbeck 1165781 (LD!); Bosnia: in pasc. alp. montis Vranica pl. (Locike) - in HBL. culta, 18 July 1891-1889, S. Murbeck 1165901 (LD!); ibidem, S. Murbeck 1159481 (LD!); ibidem, S. Murbeck 1159361 (LD!); in pascuis alpinis montis Vratnica pl., 9 September 1889, S. Murbeck s.n. (WU!); SERBIA: Suvobor, Planinica, serpentinit, 29 July 1994, T. Zonjić 2892/96 (BEOU!); Tara planina, Zaovine - Vranjak Euphorbietum glabriflorae, serpentin, 9 July 2000, V. Stefanović, S. Jovanović, S. Vukojičić 14251 (BEOU!); Bosnia, Travnik [...], $1000 \mathrm{mts}$, June 1908, E. Brandis s.n. (PI-GUAD!); MONTENEGRO: in decliv. gram. montis Bjelasica pl., c. 1700 m., 19 August 1889, S. Murbeck 1159661 (LD!); ibidem, S. Murbeck 1165961 (LD!); Durmitor, Boljske grede, July 1983, V. Stefanović 2450 (BEOU!); Durmitor, Žabljak livade, 1600 m, 7 July 1974, V. Stefanović 1548/89 (BEOU!); Durmitor, Komarnica (Boljske grede), 7 July 1989, V. Stefanović, S. Jovanović 1119/89 (BEOU!); Durmitor, uz obalu Modrog j., 9 August 1975, V. Stefanović, B. Stefanović 37 (BEOU!); Durmitor, Virak Fagetum, krečnjak, 1400 m, 12 July 1997, D. Lakušić, G. Tomović 5873 (BEOU!); Durmitor, Virak livade, krečnjak, 1400 m, 12 July 1997, D. Lakušić, G. Tomović 5896 (BEOU!); Durmitor, Sevarita lokva, prati (Festuco rubrae-Agrostetum capillaris), 1400 m, 6 July 1996, D. Lakušić, F. Conti, G. Tomović 9322 (APP!); ibidem, D. Lakušić, F. Conti, G. Tomović s.n. (BEOU!); Monte Prokletije, Popadija - Zuto prlo, 42³1'986"N, S 1945'213"E (UTM-ED50), Festuco-Seslerietea, limestone, 1900 m, 18 July 2003, D. Lakušić, F. Conti, Z. Bulić, M. Niketić, G. Ciaschetti, G. Tomović, S. Adžiablahović 31611 (APP!); Štirni do, Gackove grede, 8 August 1984, s. coll. $1825 / 89$ (BEOU!).

Knautia dinarica subsp. silana:-ITALY. Abruzzo: M. Secine presso Polledrara (Palena), prati umidi, 1700-1800 m, 19 June 1997, F. Conti 13474 (APP!); Polledrara, Secine (Palena), 430312N, 4638996E (UTM-ED50), 1730 m, 20 July 2006, F. Conti 33685 (APP!); ibidem, F. Conti 33686 (APP!); ibidem, F. Conti 33687 (APP!); ibidem, F. Conti 33688 (APP!); ibidem, F. Conti 33689 (APP!); ibidem, F. Conti 33690 (APP!); ibidem, F. Conti 33691 (APP!); ibidem, F. Conti 33692 (APP!); ibidem, F. Conti 33693 (APP!); ibidem, F. Conti 33694 (APP!); M. Secine, Polledrara (Palena), $41^{\circ} 53.864^{\prime} \mathrm{N}, 14^{\circ} 09.174^{\prime} \mathrm{E}$ (UTM-ED50), $1700 \mathrm{~m}, 24$ June 2006, F. Conti 33871 (APP!); ibidem, F. Conti 33908 (APP!); ibidem, F. Conti 33909 (APP!); ibidem, F. Conti 33910 (APP!); ibidem, F. Conti 33911 (APP!); ibidem, F. Conti 33912 (APP!); ibidem, F. Conti 33913 (APP!); Basilicata: Piano Ruggio (Potenza), Pollino, Viggianello, 13 August 2009, L. Bernardo, D. Gargano, L. Peruzzi 22002 (CLU!); ibidem, L. Bernardo, D. Gargano, L. Peruzzi 22003 (CLU!); ibidem, L. Bernardo, D. Gargano, L. Peruzzi 22004 (CLU!); Piano Ruggio (Potenza), lungo la strada, versante nord del Massiccio del Pollino, Viggianello, 1520-1550m, 27 June 2012, L. Bernardo 21997 (CLU!); ibidem, L. Bernardo 21998 (CLU!); ibidem, L. Bernardo 21999 (CLU!); ibidem, L. Bernardo 22000 (CLU!); ibidem, L. Bernardo 22001 (CLU!); ibidem, L. Bernardo 22011 (CLU!); Calabria: Loc. Calabria, in ditione Longobucco, loco Fossiata dicto, in herbosis humidis, alt. 1300 m, solo granitico, 7 August 1921, A. Fiori s.n. (FI!, three specimens); ibidem (PI!); La Sila (Calabria), faggeta lungo l'Ampollino a S, m. 1300, 14 July 1951, G. Negri, G. Sarfatti, A. Contardo s.n. (FI!); La Sila (Calabria), Lorica, 8 Km. a W, prato su terreno discretamente profondo - m. 1300, 14 July 1951, G. Negri, G. Sarfatti, A. Contardo s.n. (FI!); La Sila (Calabria), Regione Ciricilla, zona piana umida - m. 1370, 27 June 1950, G. Sarfatti, R. Corradi s.n. (FI!); La Sila (Calabria), Molarotta - Stazione Alpeggio pascolo umido - m. 1130, 23 June 1950, G. Sarfatti, R. Corradi s.n. (FI!); Calabria - Sila, Fossiata (Longobucco), 29 July-3 August 1918, alt. 1300 m, solo granitico, A. Fiori s.n. (FI!); Sila di Savelli, margine della pineta, 1300 m, 1-2 July 1917, M. Guadagno 508 (PI-GUAD!); Fallistro, lungo la strada che porta ai "Giganti della Sila", Sila Grande, prov. Cosenza, Calabria, $1400 \mathrm{~m}$, margine di strada e radure di bosco, 33S XD 26.53, 29 June 2005, L. Bernardo 20009 (CLU!); ibidem, L. Bernardo 20013 (CLU!); ibidem, L. Bernardo 20014 (CLU!); ibidem, L. Bernardo 20015 (CLU!); Ciricilla, nei pressi del centro abitato, Sila Piccola, Calabria, $1400 \mathrm{~m}$, ambiente umido, 7 July 2005, L. Bernardo 20011 (CLU!); Calabria: Sila Grande, nei pressi dello svincolo per Camigliatello (Cosenza), 1196 m, radura in pineta, 7 July 2006, L. Peruzzi, D. Gargano, S. Carlson 21148 (CLU!); Sila Grande, Valle S. Bernardo, prov. Cosenza, Calabria, 1350 m, rimboschimento a Pinus laricio, 13 July 2011, L. Bernardo 22006 (CLU!); Pisarello, lungo la strada per M.te Gariglione, Sila Piccola, Prov. di Catanzaro, Calabria, 1600 m, prato arido in estate, 28 July 2010, L. Bernardo, D. Gargano, N.G. Passalacqua 22005 (CLU!). 